\title{
Az emberölések számának radikális csökkenése Magyarországon
}

\section{SIVADÓ Máté ${ }^{\oplus}$}

\begin{abstract}
Magyarországon a bünügyi statisztikában rögzített büncselekmények száma zavarba ejtően csökken. Az 1998-as csúcs óta az összbünözési mutató kevesebb mint a harmadára zuhant. Ezen belül még kiugróbb az emberölések számának csökkenése, amely az ötödére esett vissza. Sokan gyanakodva szemlélik a statisztikai mutatókat, és a hatóság könyvelési módszereinek tudják be a kedvező számokat. Kutatásom során azt vizsgálom, mi állhat a radikális csökkenés hátterében.
\end{abstract}

Kulcsszavak: kriminológia, bünügyi statisztika, emberölések száma, rendőrség szavahihetősége

\section{Bevezetés}

Az emberölések számának alakulása sok esetben vált ki zajos szakmai vitát. Magyarországon 1994 óta radikális csökkenés tapasztalható e tekintetben, ami zavarba ejti a szakembereket is. A legjobb szándékú emberben is felmerül a logikus kételkedés, látván a csökkenés mértékét történelmi léptékben hihetetlenül rövid idő alatt.

2016-2017-ben felmerült, hogy az Eurostat ${ }^{2}$ által publikált magyarországi emberölési adatok nem azonosak a hazai statisztikai adatokkal, nem mutatnak olyan kedvező számokat, mint ez utóbbiak. A különbséget az adta, hogy a magyar adatokban kizárólag a szándékos és befejezett emberölések szerepeltek, az európai statisztikában pedig benne voltak a kísérleti vagy előkészületi stádiumban megrekedt vagy gondatlanságból elkövetett emberölési adatok is. ${ }^{3}$

Az egyre kedvezőbb hazai emberölési adatokkal szemben kritikus véleményformálók szakmai fórumokon azt is felvetették, hogy a megoldatlan emberöléseket inkább halált okozó testi sértésnek vagy foglalkozás körében elkövetett halált okozó gondatlan veszélyeztetésnek minősítik a hatóságok az emberölési statisztika javítása érdekében.

Ezek a vélemények rendészettudományi és gyakorlati rendőri körökben is széles körben elterjedtek.

\footnotetext{
Sivadó Máté PhD. r. őrnagy, Nemzeti Közszolgálati Egyetem Rendészettudományi Kar Kriminológiai Tanszék, adjunktus.

Máté Sivadó PhD, Police Major, University Of Public Service Faculty of Law Enforcement Department of Criminology, Assistant Professor. E-mail: Sivado.Mate@uni-nke.hu

2 European Statistic Office.

3 Országos Kriminológiai Intézet: Közlemény (2019).
} 


\section{A kutatás módszertana}

Kutatásom során beszereztem a Magyarországon elkövetett emberölések adataira vonatkozó, elérhető statisztikákat, így az Egységes Nyomozóhatósági és Ügyészségi Bűnügyi Statisztika (ENYÜBS), a Bűnügyi Statisztikai Rendszer (BSR), a Központi Statisztikai Hivatal, valamint az Országos Statisztikai Adatfelvételi Program (OSAP) adatait.

Adatkéréssel fordultam a Belügyminisztériumhoz, az Országos Rendőr-főkapitányság Bűnügyi Főigazgatóság Bűnügyi Elemző-Értékelő Főosztály Bűnügyi ElemzőÉrtékelő Osztályhoz, a Nemzetközi Bűnügyi Együttműködési Központhoz (NEBEK) és a Központi Statisztikai Hivatal (KSH) Népszámlálási és Népesedési Statisztikai Főosztályához.

Talán a legfontosabb, hogy különbséget tegyünk az ENYÜBS és az Ügyforgalmi Statisztika adatai között. Az előbbi kimenő jellegű (output) statisztika, tehát a büntetőeljárás nyomozati szakaszának lezárultakor készül. Így nem azt mutatja, hogy a vizsgált időszakban hány bủncselekmény történt, hanem azt, hogy hány nyomozás fejeződött be. Az eljárások időtartama változó, így ezt a torzítást a rendszer adatainak elemzésébe bele kell számolni. Az Ügyforgalmi Statisztika adatai az aktuálisan folyamatban lévő nyomozások adatait tartalmazza, így időben aktuálisabb. Utóbbi adatokról az ORFK nem ad hivatalos tájékoztatást. Ennek fő oka, hogy a folyamatban lévő eljárások adataiból messzemenő következtetések levonása félrevezető lehet. Kiderülhet időközben, hogy a folyamatban lévő ügyet a hatóságok átminősítették, bűncselekmény vagy elkövető hiányában megszüntették vagy felfüggesztették. 2019. évtől rendelkezésre állnak még a KBS-adatok, amely azt mutatja, hogy hány feljelentés történt. Ezt az ORFK kutatási célra rendelkezésre bocsátja. Jelen publikáció kéziratának lezárásáig ezen adatokat még nem szereztem be, de újabb publikációban ismertetni fogom.

\section{Az erőszak globális csökkenése}

„Az emberölések alakulásának vizsgálata során a mennyiségi mutatók mellett ugyanolyan fontossággal bírnak a minőségi változások is, ezért az emberölés minősített eseteinek előfordulási aránya szintén jelentős szempontot képvisel az elemzések során. Az egyes bűncselekmények számának nemzetközi összehasonlítása a büntetőjogi szabályozások különbözősége miatt nehézségekbe ütközhet. Azonban az emberölés alapesetének meghatározása egységes abban a tekintetben, hogy lényegében a más ember halálának szándékos okozásával megvalósított cselekményeket értik alatta, ezek mindenhol bűncselekménynek minősülnek és elsősorban a minősítő körülmények vonatkozásában mutatkoznak eltérések. A szándékos emberölés közel azonos definiálása révén tehát lehetővé válik annak nemzetközi összehasonlítása."4

Bolyky Orsolya: Az emberölések jogi és kriminológiai jellemzôi, különös tekintettel a mentális tényezők büntetőjogi értékelésére. Doktori értekezés. Budapest, Pázmány Péter Katolikus Egyetem, 2017. 
Kutatásom során a felmerült kétségeket kívánom megvizsgálni, illetve a trendet nemzetközi összehasonlításban elemezni.

„Az élet minden területén megfigyelhető az erőszak visszahúzódása. Egészen más a mindennapi élet, ha folyamatosan félnünk kell, hogy elrabolnak, megerőszakolnak vagy meggyilkolnak, és nehéz megvalósítani a fejlett múvészetet, tanulást vagy kereskedelmet, ha a támogatásukra szolgáló intézményeket már megépítésük pillanatában kifosztják vagy felgyújtják. Az erőszak történelmi pályaíve nemcsak azt érinti, ahogy éljük az életünket, hanem azt is, ahogy értelmezzük azt. Mi is lehetne fontosabb az élet értelmével és céljával kapcsolatos felfogásunk szempontjából, mint annak eldöntése, hogy az emberiség erőfeszítései hatására jobb vagy rosszabb dolgunk lett az idők során? És mindenekelőtt hogyan értelmezzük a modernséget - azt, hogy az individualizmus, a kozmopolitanizmus, a logika és a tudomány erői hogyan ásták alá a családot, a törzset, a hagyományt és a vallást? Nagyon sok múlik azon, hogyan tekintünk e változás örökségére: úgy látjuk-e a világot, mint a bűn, a terrorizmus, a népirtás és a háború rémálmát, vagy olyan időszakként értékeljük, amely - a történelem léptékével mérve - soha nem látott békés, áldott együttélést hozott." ${ }^{5}$

Pinker könyvében öt pszichológiai rendszert, vagy - ahogyan ő nevezi - démont ismertet; ennek értelmében vagy eszközként folyamodunk erőszakhoz, vagy a dominanciánkat akarjuk kifejezni vele, de az is előfordul, hogy bosszút akarunk állni valamilyen vélt vagy valós sérelemért, esetleg valamilyen ideológia nevében gondoljuk úgy, hogy a cél szentesíti az eszközt. Van még egy démon, amellyel számolnunk kell: természetesen az is elképzelhető, hogy szadisták vagyunk.

Nemcsak démonokkal, angyalokkal is el vagyunk látva - a mú eredeti címe (The Better Angels of Our Nature: Why Violence Has Declined) pont azokra a jellemvonásainkra utal, amelyek azt súgják a legtöbbünknek, hogy ne essünk egymás torkának, bármilyen szórakoztatónak is tűnik elsőre az ötlet. Ebben nagy szerepet játszhat az empátia - bele kell gondolnunk, hogy bár örömöt okozna valakit jól orrba vágni, ha az ő helyében lennénk, valószínűleg nem örülnénk túlságosan. Az angyalok közé tartozik még az önmérséklet, az erkölcsi érzék, végezetül pedig a józan ész: ez teszi lehetővé számunkra, hogy meglássuk a nagy összefüggéseket, és belegondoljunk abba, hogy mi teheti könnyedebbé és biztonságosabbá az életünket. ${ }^{6}$

Az Amerikai Egyesült Államokban az 1990-es évek elején százezer lakosra 750 erőszakos búncselekmény esett. A mutató 2013-ra több mint 50\%-kal csökkent, és százezer lakosra már csak 368 erőszakos bűncselekmény jutott. 1980 és 2014 között 39\%-kal csökkent az erőszakos bűnözési ráta, és 1993-2016 között az áldozattá

Steven Pinker: Az erôszak alkonya. Budapest, Typotex, 2018. 13.

Dippold Ádám: Az erőszak alkonya: Bármilyen erőszakosnak is tűnik a világ, egyre kevésbé gyilkoljuk egymást. Qubit, 2018. július 24. 
válás gyakorisága is $20 \%$-os csökkenést mutatott, az időszakon belül is kiemelkedő mértékben, 40\%-kal csökkent az 1995 és 2010 közötti években. ${ }^{7}$

\section{A szándékos, befejezett emberölések alakulása Magyarországon 1990-2020 között}

Magyarországon a rendszerváltás óta 1994-ben történt a legtöbb (310) szándékos, befejezett emberölés, 2019-ben pedig a legkevesebb, 58. A csúcspont óta a csökkenés folyamatos, 2020-ban tapasztalhattunk csak némi növekedést (ENYÜBS).

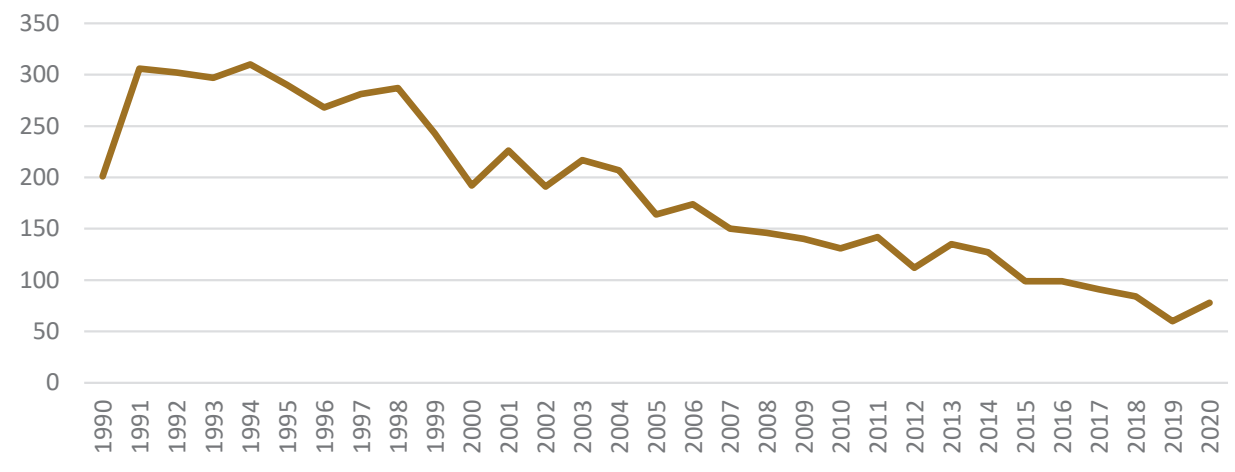

1. ábra: Szándékos, befejezett emberölések száma Magyarországon, 1990-2020

Forrás: ORFK Bünügyi Elemző-Értékelő Főosztály

Mindeközben azt láthatjuk, hogy az Európai Unióban is jelentős visszaesés tapasztalható az emberölések tekintetében. Legszembetűnőbb a férfiak sérelmére elkövetett emberölések számának csökkenése a vizsgált időszakban. A százezer lakosra jutó szám 1,9 esetről 0,9 esetre csökkent 2002 és 2016. között. A nemzetközi adatok összehasonlíthatósága természetesen sok kérdést felvet, ahogy azt Mátyás Szabolcs már megírta. ${ }^{8}$

Maria Tcherni-Buzzeo: The "Great American Crime Decline": Possible Explanations. In Marvin D. Krohn et al. (szerk.): Handbook on Crime and Deviance. 2018. 309-335.

8 Mátyás Szabolcs: Bünözésföldrajz. Egyetemi jegyzet, Debrecen, Didakt, 2020. 34. 


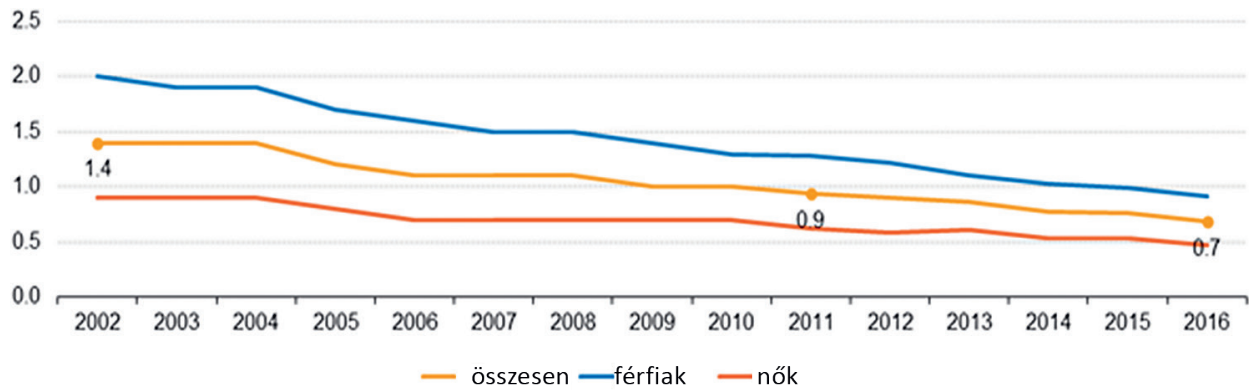

2. ábra: Az emberölések aránya százezer lakosra vetitve nemek szerint az Európai

Unióban 2002-2016 között

Forrás: Eurostat

\section{Eltúnések alakulása Magyarországon}

A megfogalmazott kritikák között elhangzik az is, hogy a rendőrség eltűnési adatok közé rejti el egyes emberölések adatait. Ezért az eltűnések adatait is vizsgálat alá vontam a tárgyalt időszakban. A Hermon Körözési nyilvántartási rendszer adatai alapján 2014-2020 között (éves bontásban) az alábbiak szerint alakult az eltűnés miatt elrendelt körözések száma:

1. táblázat: Eltűnések miatt elrendelt körözések száma a Hermon Körözési nyilvántartási rendszer adatai alapján

\begin{tabular}{|l|r|r|r|r|r|r|r|c|}
\hline Év & $\mathbf{2 0 1 4}$ & $\mathbf{2 0 1 5}$ & $\mathbf{2 0 1 6}$ & $\mathbf{2 0 1 7}$ & $\mathbf{2 0 1 8}$ & $\mathbf{2 0 1 9}$ & $\mathbf{2 0 2 0}$ & $\mathbf{2 0 2 1 . 0 5 . 2 4 - i g}$ \\
\hline $\begin{array}{l}\text { Gyermekkorú / } \\
\text { 0-14 év/ }\end{array}$ & 3864 & 2911 & 2731 & 3117 & 2900 & 3123 & 2762 & 1151 \\
\hline Fiatalkorú /14-18 év/ & 13021 & 16368 & 15968 & 15907 & 15499 & 15472 & 15482 & 6289 \\
\hline $\begin{array}{l}\text { Kiskorú elrendelt } \\
\text { összesen }\end{array}$ & $\mathbf{1 6 ~ 8 8 5}$ & $\mathbf{1 9 2 7 9}$ & $\mathbf{1 8 ~ 6 9 9}$ & $\mathbf{1 9} \mathbf{0 2 4}$ & $\mathbf{1 8 3 9 9}$ & $\mathbf{1 8 5 9 5}$ & $\mathbf{1 8 2 4 4}$ & $\mathbf{7 4 4 0}$ \\
\hline Felnőttkorú & 3190 & 3543 & 3584 & 3193 & 3084 & 2955 & 2468 & 826 \\
\hline Összesen & $\mathbf{2 0 ~ 0 7 5}$ & $\mathbf{2 2 ~ 8 2 2}$ & $\mathbf{2 2 ~ 2 8 3}$ & $\mathbf{2 2 ~ 2 1 7}$ & $\mathbf{2 1 ~ 4 8 3}$ & $\mathbf{2 1 5 5 0}$ & $\mathbf{2 0 7 1 2}$ & $\mathbf{8 2 6 6}$ \\
\hline
\end{tabular}

Forrás: NEBEK

A Hermon Körözési nyilvántartási rendszerből kigyűjtött statisztikai adatok alapján az elrendelt körözések száma az elmúlt években szinte stagnál, a tendenciákban jelentős változás nem történt.

Fontos kiemelni, hogy a rögzített körözések száma nem azonos az eltűntek számával. Kiskorúak esetében a körözések magas számát jellemzően a gondozási helyükről engedély nélkül távozott, vagy oda az előírt időben vissza nem térő, ideiglenes 
hatállyal elhelyezett, nevelésbe vett kiskorúak száma jelenti. Ezekben az esetekben nem beszélhetünk a szó hagyományos értelmében vett eltúnésről, mert az esetek többségében általában ismert a kiskorú tartózkodási helye (például a gyermek megszökött gondozási helyéről). Előfordul, hogy egy kiskorú egy évben akár több alkalommal is engedély nélkül távozik a kijelölt gondozási helyéról. Értelemszerűen, ahányszor az illető megszökik, ez annyi körözési eljárás elindítását generálja, és ezek egyenként jelennek meg a statisztikai rendszer kimutatásában.

Kiskorúak eltúnésének hátterében a szülők közötti, vagy a szülő és gyermek közötti konfliktushelyzet, gyermekelhelyezési vita, esetleg gyermekvédelmi hatósági intézkedés megakadályozása is állhat. A gyermekotthonban, lakásotthonban és nevelőszülőnél elhelyezett kiskorúak engedély nélküli távozásaik során jellemzően a szüleikhez, rokonaikhoz, illetve barátaikhoz szöknek vissza.

Az, hogy mikor kerül elő az eltűnt személy, számos tényező függvénye. Befolyásolják az eltünés körülményei, oka és helyszíne.

Az eltünt kiskorúak mintegy 30\%-a a bejelentés megtétele után egy napon belül, újabb 30\%-a a bejelentés után egy héten belül, míg 35\%-a egy hónapon belül előkerül.

A fennmaradó 5\%-ba tartoznak azok a kiskorúak, akiknek az eljáró hatóság az adatgyújtés során felmerült információkra figyelemmel vélelmezi a tartózkodási helyét, csak egyéb okból nehézkes a felkutatásuk (külföldön tartózkodnak, családja, barátai bújtatják).

A NEBEK Körözési Nyilvántartó és Szakirányító Főosztálya szakirányító tevékenységén belül kiemelt figyelmet fordít a felnőttkorú személyek vonatkozásában is az eltúnési ügyek kezelésére. Ezekben az ügyekben átfogó, a hatékonyságot növelő szisztémát dolgoztak ki, amelynek bevezetése a 2017-2018. években kezdődött, első lépcsőben az országos szinten meglévő több mint 800 ügy feltérképezésével. Az esetek áttanulmányozása során megállapítható, hogy jellegüket tekintve az alábbi ügytípusok fordulnak elő a körözési rendszerben:

- a gyermek-, illetve fiatalkorúakra jellemző olyan eltúnések, amelyek csak rövid ideig állnak fenn (majd többnyire ugyanazon személynél ismétlődnek, állandósulnak az engedély nélküli távozások, majd a személyek megkerülnek);

- az időskorú személyekre jellemző, általában demenciából adódó távozás, amely néha halállal végződhet, azonban holttest nem minden esetben kerül elő;

- kórházi kezelésről pszichés, illetve egyéb probléma miatt távozók;

- öngyilkossági szándékkal távozók, egy részük holttestét nem találják meg;

- az eltûnt személy életviteléből adódó (különösen alkoholizmus, kábítószerfüggőség folyományaként kialakuló leépülésből bekövetkező halálesettel végződő) eltűnés, amely során nem kerül elő a keresett személy holtteste;

- kisebb számban előfordul önkéntes távozás (családi, rokoni, illetve párkapcsolatokból adódó menekülés). 
A jelenlegi, 2014. január 1-jén hatályba lépett körözési törvény ${ }^{9} 90$ évben határozza meg az adatkezelési időt, amely ezt megelőzően 20 év volt, így ez folyamatos ügyszámnövekedést generál a korábbiakhoz képest, mivel 20 év után sem kerülnek ki a rendszerből a korábban elrendelt körözések.

$\mathrm{Az}$ elmúlt év statisztikai adatainak elemzése alapján kijelenthető, hogy a 90 napnál régebben keresett felnőtt eltủntek száma érdemben nem változik, 800-825 között alakul. Folyamatosan monitorozzák a régi és az újonnan bejelentett ügyeket, és a szükséges elemzői, adatgyưjtési tevékenységet elvégzik/szakirányítják a főosztály részéről. ${ }^{10}$

A fentiek alapján megállapítható, hogy az eltűnések számának alakulása nem ad okot arra a feltételezésre, hogy az eltűnt személyek között nagy számban lennének látenciában maradt emberölések áldozatai.

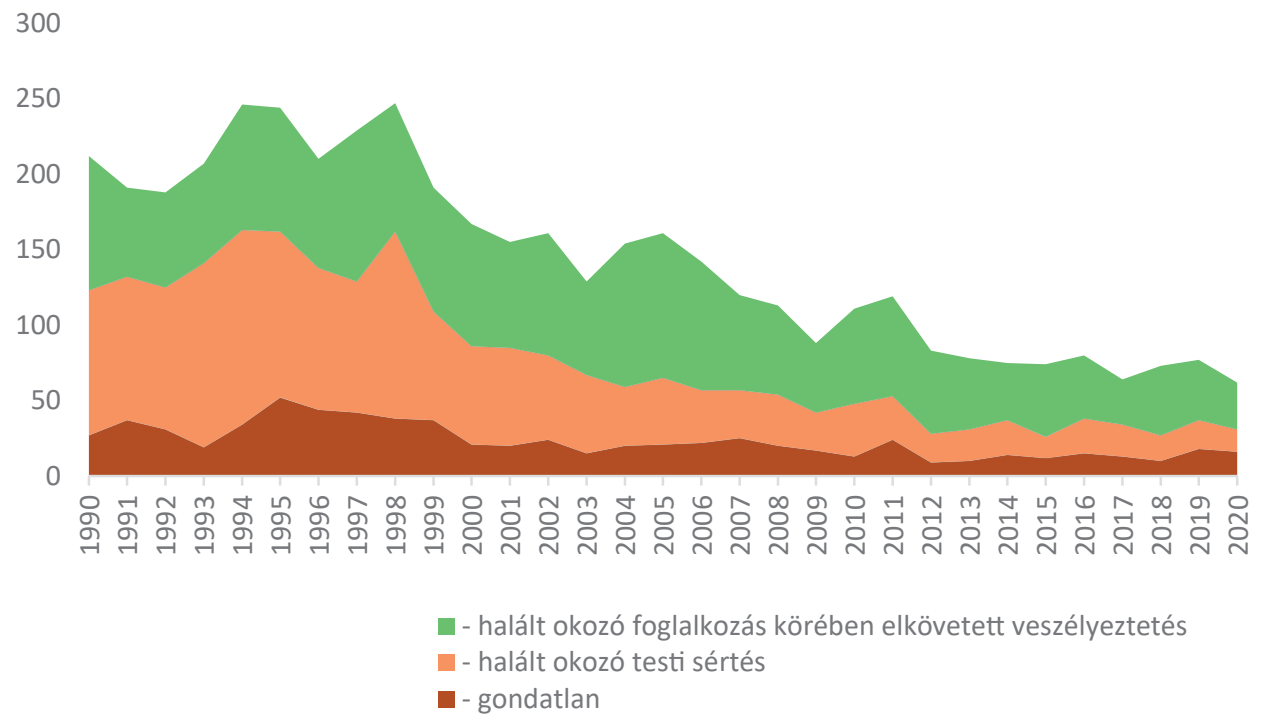

3. ábra: Az emberölésen kivuull más, a sértett halálát okozó büncselekmények alakulása Magyarországon

Forrás: ORFK Bünügyi Elemzö-Értékelő Főosztály

2013. évi LXXXVIII. törvény a körözési nyilvántartási rendszerről és a személyek, dolgok felkutatásáról és azonosításáról.

10 Nemzetközi Bűnügyi Együttműködési Központ Nemzetközi Bűnügyi Igazgatóság Körözési Nyilvántartó és Szakirányító Főosztály által biztosított adatokból. 


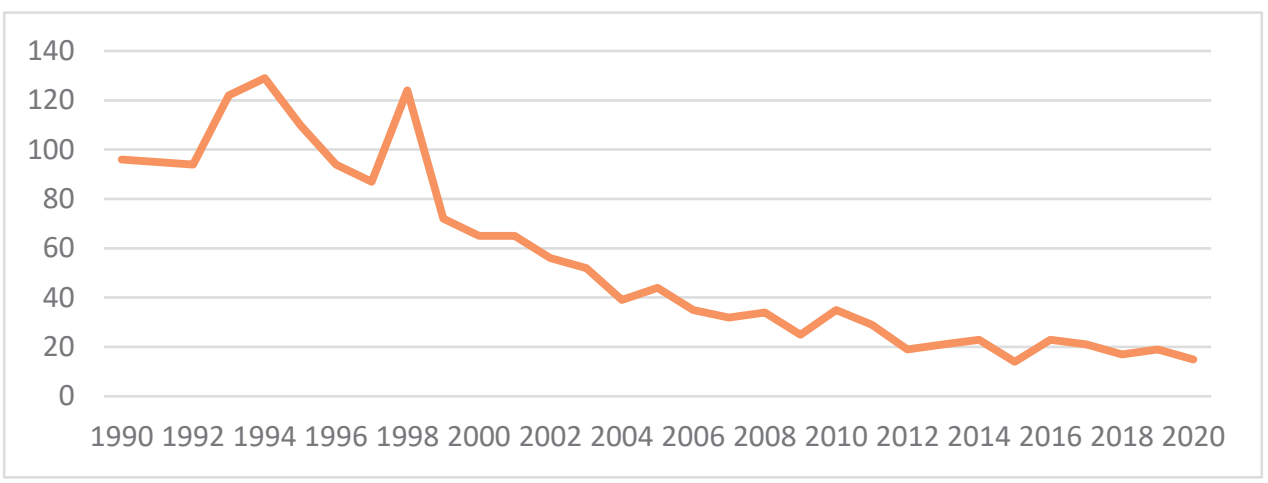

4. ábra: Halált okozó testi sértés büncselekmény elkövetése Magarországon 1990 és 2020 között

Forrás: ORFK Bünügyi Elemző-Értékelő Főosztály

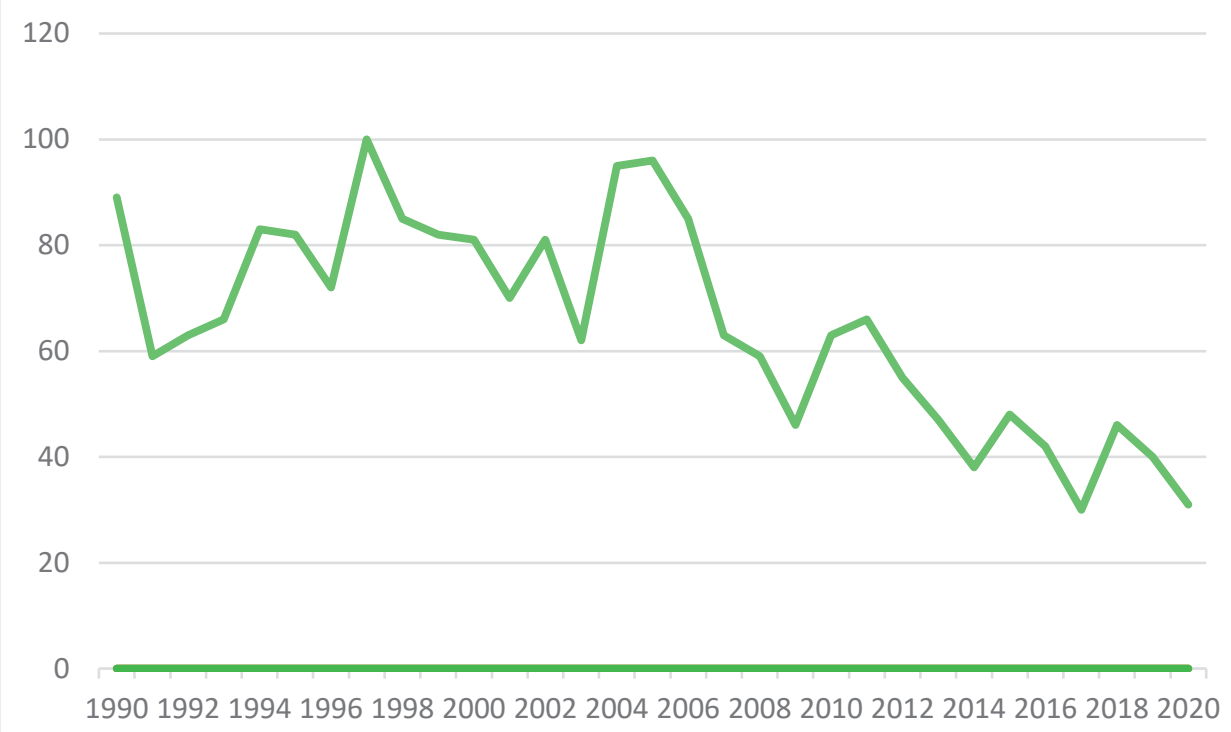

5. ábra: Halált okozó foglalkozás körében elkövetett veszélyeztetés büncselekmény elkövetése Magyarországon

Forrás: ORFK Bünügyi Elemzö-Értékelő Főosztály 


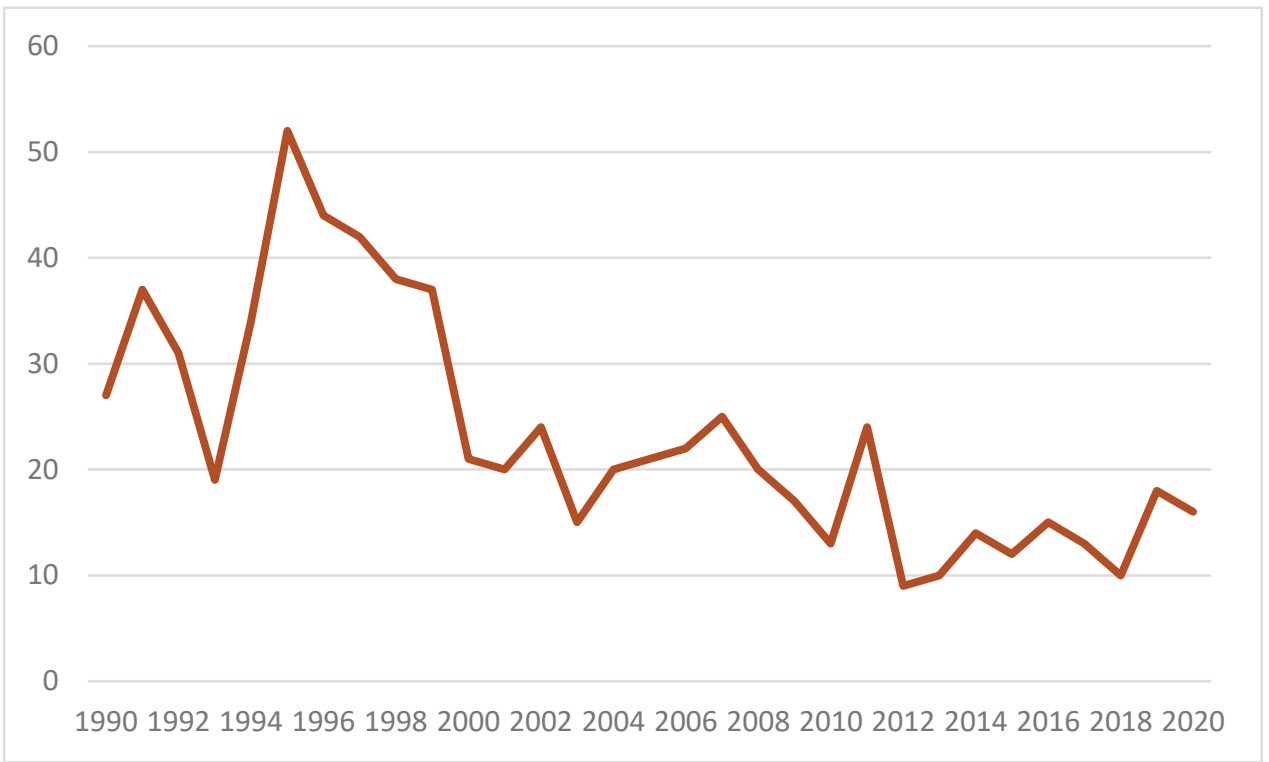

6. ábra: Gondatlanságból elkövetett emberölés büncselekmények alakulása Magyarországon

Forrás: ORFK Bünügyi Elemző-Értékelő Főosztály

A diagramok tanúsága szerint egyértelmúen cáfolható az a vélekedés, miszerint a szándékos, befejezett emberölések számának csökkenése mögött az van, hogy a sértett a halálát okozó, nem emberölést megvalósító bủncselekmények száma növekedett volna egyfajta hatósági „átkönyvelés” eredményeképpen.

Mind a halált okozó testi sértés, mind a gondatlanságból elkövetett emberölés, mind a halált okozó, foglalkozás körében elkövetett veszélyeztetés vonatkozásában a szándékos, befejezett emberöléshez hasonló, vagy attól is nagyobb esetszámcsökkenést regisztrált az ENYÜBS a vizsgált 1990-2020 közötti időszakban.

\section{Rendkívüli halálesetek}

A fenti mutatókon kívül a rendkívüli halálesetek számát láttam relevánsnak megvizsgálni, mivel sokszor éri a rendőrséget az a vád, hogy ha nem lát lehetőséget egy emberölés elkövetőjének felderítésére, akkor az ügyet eleve rendkívüli halálesetként tartja nyilván. Megkerestem az Országos Rendőr-főkapitányságot, hogy tájékoztassanak, hogyan alakultak 1990 és 2020 között Magyarországon a rendkívüli halálesetek számai. 
A válasz szerint az 1990-2020. év között bekövetkezett rendkívüli halálesetek számának alakulásáról a Rendőrség nem rendelkezik hivatalos statisztikával. A rendkívüli halál esetén követendő rendőri eljárásról szóló 24/2014. (VII.11.) ORFK utasítás 77. pontja írja elő az adatszolgáltatási kötelezettséget a területi rendőri szervek részére, amelynek tartalma azonban az eltelt évek alatt folyamatosan bővült és módosult.

A hivatalos statisztikáról szóló 2016. évi CLV. törvény 30. § (1) bekezdése alapján a Központi Statisztikai Hivatal rendelkezik hiteles és naprakész információval a beérkezett halottvizsgálati bizonyítványok alapján a halálesetek számáról és minden olyan egyéb adatról, amely e bizonyítvány kötelező tartalmi eleme.

Ezt követően megkerestem a Központi Statisztikai Hivatalt, ahol az alábbi adatokat bocsátották a rendelkezésemre: ${ }^{11}$

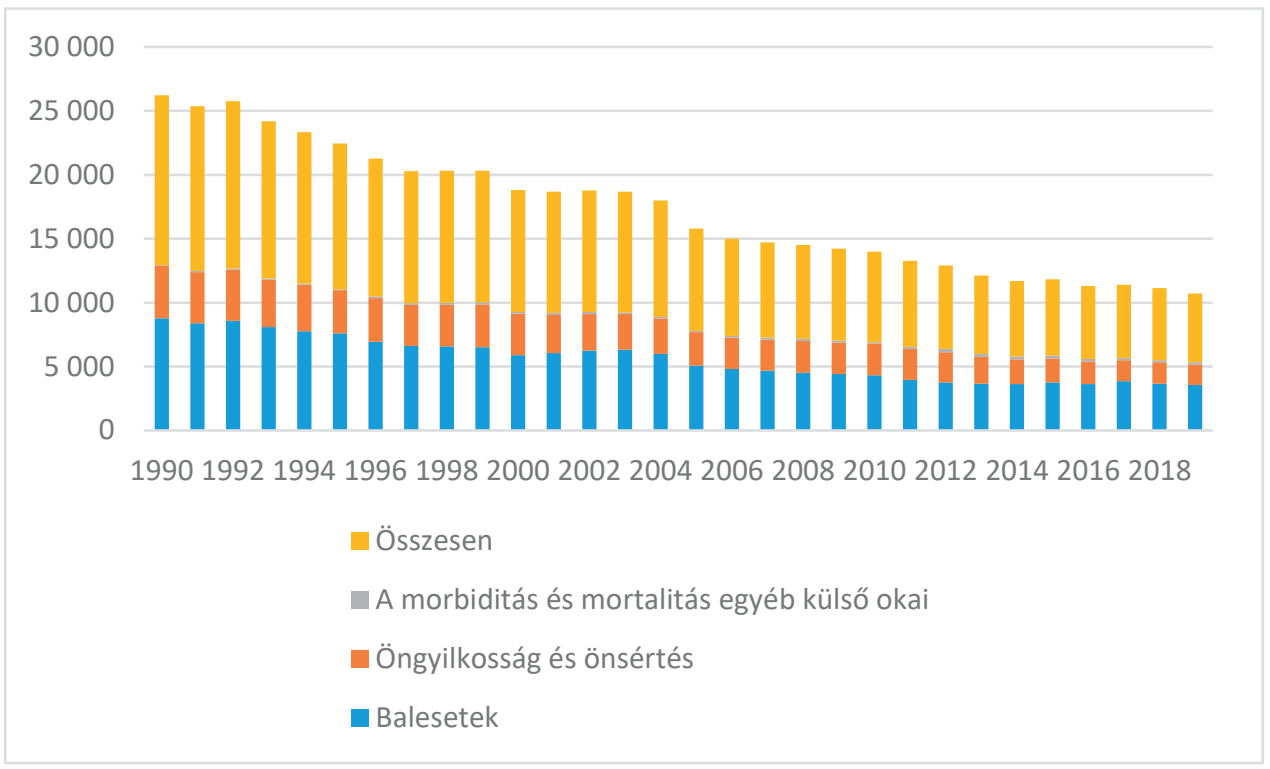

7. ábra: Nem természetes halálesetek Magyarországon 1990-2018 között

Forrás: KSH (Az adatok 1990-2019. állnak rendelkezésemre. Az adatmennyiség miatt az ábra csak páros évenként jeleníthetö meg, így a 2019-es év lemaradt.)

Az adatokból jól látszik, hogy a mortalitás e rendkívüli okaiban is jelentős csökkenés zajlott az elmúlt 20 évben. Ezek alapján cáfolható az a feltételezés, hogy a nyomozó

\footnotetext{
11 A táblázat azokat a halálokokat tartalmazta, amelyek a nem természetes halálesetek körébe tartoznak (baleset, öngyilkosság, egyéb külső okok), amely az egészségügyről szóló 1997. évi CLIV. törvény 218. § (1) bekezdés b) pontja (rendkívüli halál) szerinti besorolást követi, de nem teljesen azonos azzal. A KSH által küldött táblázatban a testi sértés által okozott halálesetek is benne voltak, de azokat a rendőrség nem a rendkívüli halálesetekre vonatkozó eljárásban, hanem büntetőeljárás keretében vizsgálja.
} 
hatóságok a vélhetően nem felderíthető emberölési ügyeket nagy számban rendkívüli halálesetként regisztrálják. Írom ezt annak ellenére, hogy több később felderített ügyből kiderül, hogy elszórtan létezik ilyen tendencia.

\section{Látencia az emberölési ügyekben}

A látencia azt jelenti, hogy az adott bűncselekmény nem jut a hatóság tudomására. Emberölés esetén ez beláthatóan sokkal kisebb arányban valósul meg, mint a vagyon elleni bűncselekmények körében. Egy ember eltűnése általában feltűnik valakinek. A családnak, ennek híján a barátoknak, cimboráknak, esetleg a hatóságoknak. A másik lehetőség, hogy előkerül az elhunyt személy holtteste, de külsérelmi nyom nem látható rajta, és így boncolás híján a halál okát valamilyen természetes okban vagy egyéb okban állapítja meg az eljáró orvos. A látenciát okozhatja még, ha a személy eltűnéséről a hatóságokat értesítik, de az előtalálásra tett intézkedések nem vezetnek eredményre. Ilyenkor hosszú távon benne marad a személy eltüntként a Körözési információs rendszerben.

Az Országos Rendőr-főkapitányság (ORFK) új stratégiákat dolgozott ki az emberölési ügyekben meglévő látencia csökkentésére. Speciális módszertan szerint dolgoznak a 90 napon túli felnőtteltűnések ügyében. Ezeket az ügyeket egyedileg kivizsgálják, és ha gyanú merült fel, hogy bűncselekmény állhat az eltúnés mögött, az ORFK-szakirányítás kezdeményezi az illetékes megyei rendőr-főkapitányságon, hogy vizsgálják ki alaposabban az ügyet, bevonva a Nemzeti Nyomozó Irodát is.

Az 1990-es évektől kezdve ezres nagyságrendű azoknak a felnőtteknek a száma, akiket köröz a rendőrség eltűnés miatt, és körülbelül 1000 ismeretlen holttestet vagy testrészt próbál beazonosítani ugyanebben az időszakban. Ennek eredményeképpen az azonosítatlan holttestek közül 20 kapcsán állapította meg a hatóság, hogy a sérelmére emberölést követtek el. Az ismeretlen, de később azonosított holttestek esetén sok esetben az derül ki, hogy senki nem kereste az illetőt.

$\mathrm{Az}$ ORFK az ilyen személyek mielőbbi azonosítása érdekében is keresi a megoldás lehetőségét. Kezdeményezik a Közigazgatási és Elektronikus Közszolgáltatások Központi Hivatalánál (KEKKH), hogy kik azok a személyek, akik nem reagálnak a hatóság megkeresésére, például, amikor új okiratuk készül el.

Szintén az ORFK kezdeményezte a legutóbbi időben, hogy a megyei rendőrfőkapitányságok vizsgálják újra a rendkívüli haláleseteket a 2016 és 2020 közötti időszakra.

\section{8. Összegzés}

Összefoglalóan elmondható, hogy azok az vélemények, amelyek az emberölések hazai csökkenése mögött statisztikai trükközéseket sejtettek, nem igazolhatók. A kutatás 
jelenlegi állása szerint valósnak kell elfogadnunk a csökkenő számadatokat. Gyakori érv még, hogy az ENYÜBS-adatok azok output jellege miatt nem az aktuális helyzetet mutatják, mivel tartalmazzák az ügyek elhúzódása, illetve azok különbsége által okozott torzítást. Ezzel kapcsolatban kijelenthető, hogy közel húszéves trendben ezek a torzulások eltûnnek, nem érintik lényegesen az adatok értékelését.

Néhány szó a csökkenés lehetséges okairól.

„A háttértényezők közül ki kell emelni a gazdasági fellendülés és a munkanélküliség csökkenésének hatását, a demográfiai tényezőket, a bevándorlást és az olyan szakpolitikai tényezőket, mint a szabadságvesztési tartamok növekedése, illetve a szelektív semlegesítés általánossá válása. Jelentős szerepet játszik a csökkenés okai között a biztonsági eszközök elterjedése, amely mérsékelte a bűnelkövetési lehetőségeket. Ha az elkövetési lehetőségek csökkennek, akkor kevesebben követik el a bünözői karrier kezdetét jelentő első büncselekményt. A bűnözés csökkenő trendjére meghatározó befolyást gyakoroltak a demográfiai változások, különösen a bűnelkövető népesség kormegoszlását leginkább meghatározó a 15-25 éves korosztályban a fiatal férfiak számarányának csökkenése. A demográfiai változások másik oldala - az orvostudomány fejlődése és a technika előrehaladása miatt - az átlagéletkor kitolódása és az idősebb népesség életkori csoportjának jelentős számbeli növekedése. Az idősek lélekszáma elsősorban Európában növekszik: a 65 éven felüli európai népesség az elmúlt hatvan évben megtriplázódott, a hatvan évesnél idősebbek száma pedig hatszor magasabb, mint 1950-ben volt. Az életkor előrehaladtával viszont egyre kevésbé valószínú a bűncselekmény elkövetése. Speciálisan kelet-európai bűnözéscsökkenési tényező a kivándorlás: a magyar népességből például hiányzik közel félmillió vétőképes korú, nyugaton munkát vállaló fiatal." ${ }^{12}$

\section{IRODALOMJEGYZÉK}

Bolyky Orsolya: Az emberölések jogi és kriminológiai jellemzői, különös tekintettel a mentális tényezők büntetőjogi értékelésére. Doktori értekezés. Budapest, Pázmány Péter Katolikus Egyetem, 2017. Online: https://doi.org/10.15774/PPKE.JAK.2018.002

Dippold Ádám: Az erőszak alkonya: Bármilyen erőszakosnak is tűnik a világ, egyre kevésbé gyilkoljuk egymást. Qubit, 2018. július 24. Online: https:/qubit.hu/2018/07/24/az-eroszakalkonya-barmilyen-eroszakosnak-is-tunik-a-vilag-egyre-kevesbe-gyilkoljuk-egymast

Kerezsi Klára: Trend lesz-e (a jövőben is) a bünözés csökkenése? Magyar Tudomány, 181. (2020), 5. 577-590. Online: https://doi.org/10.1556/2065.181.2020.5.2

Mátyás Szabolcs: Bűnözésföldrajz. Egyetemi jegyzet, Debrecen, Didakt, 2020. Online: http://real. mtak.hu/90113/1/M\%C3\%A1ty\%C3\%A1s\%20Szabolcs_B\%C5\%B1n\%C3\%B6z\%C3\%A9sf\%C3\%B6ldrajz.pdf

12 Kerezsi Klára: Trend lesz-e (a jövőben is) a bűnözés csökkenése? Magyar Tudomány, 181. (2020), 5. 577-590. 
Országos Kriminológiai Intézet: Közlemény. Online: www.okri.hu/images/stories/Kozlemenyek/ OKRI_KZLEMNY_emberlsek_szma_vgleges_20190528.pdf

Pinker, Steven: Az eröszak alkonya. Budapest, Typotex, 2018.

Tcherni-Buzzeo, Maria: The "Great American Crime Decline”: Possible Explanations. In Marvin D. Krohn - Nicole Hendrix - Gina Penley Hall - Alan J. Lizotte (szerk.): Handbook on Crime and Deviance. 2018. 309-335. Online: https://doi.org/10.1007/978-3-030-20779-3_16

\section{Jogforrás}

2013. évi LXXXVIII. törvény a körözési nyilvántartási rendszerről és a személyek, dolgok felkutatásáról és azonosításáról

\section{ABSTRACT}

\section{Radical Decrease in the Number of Homicides in Hungary}

\section{Máté SIVADÓ}

It is a baffling fact that in Hungary, the number of crimes recorded by crime statistics is falling to a great extent. Since its peak in 1998, the overall crime rate has fallen to less than a third. Within this, the decline in the number of homicides, which fell to one-fifth, is even more pronounced. Many people look at the statistical indicators with suspicion and attribute the favourable numbers to the authority's accounting methods. In my research, I examine what may be behind the radical decrease.

Keywords: criminology, crime statistics, number of homicides, police credibility 